\title{
Improving Tax Revenue Performance in Tanzania: Does Potential Tax Determinants Matters?
}

\author{
Method S. Simbachawene* \\ School of Economics and Finance, Xian Jiaotong University, 74\# Yanta West Road, Xian, Shaanxi, China \\ *Corresponding author: 1668608941@qq.com
}

\begin{abstract}
Developing countries face challenges in achieving tax frontier, which lead to low tax capacity that cause budget imbalances and enforces government to finance recurrent expenditure or developing projects through loans, and risking a country into higher debt dependence. Performance of tax revenue caused by endogenous and exogenous factors but improving some fundamental factors in the economy tends to improve tax revenue performance significantly. This paper intends to establish evidence on potential tax determinants which influence tax revenue performance from 1999 to 2016; the analysis tested the developed hypothesis of whether potential tax-determinant influence tax performance in Tanzania. A model includes four-factors; economic, structural, institutional, and financing factors, results revealed potential tax determinants significantly influence tax revenue performance. Mining share and loan indicate positive effects and statistically significant while government effectiveness affects tax revenue negatively and significantly. Other variables; manufacturing, construction, transportation, services, the rule of law, regulation quality, and control corruption were positively affected tax revenue while foreign direct investment negatively affects tax revenue, both insignificantly. Findings suggest to emphasise more on improving share on influential sectors with caution on FDI and mining, increase dependence in non-agriculture sector, increase transformation change in industrialisation, informal sector, and urbanisation with the intention of boosting economic growth and bring more payers into the tax net.
\end{abstract}

Keywords: tax ratio, tax determinants, coefficient, Tanzania

Cite This Article: Method S. Simbachawene, "Improving Tax Revenue Performance in Tanzania: Does Potential Tax Determinants Matters?” Journal of Finance and Economics, vol. 6, no. 3 (2018): 96-102. doi: 10.12691/jfe-6-3-3.

\section{Introduction}

Tanzania is among the developing country, which experiences regular fiscal policy reforms with the intention of increasing tax revenue performances. Tax policy reforms were intended to improve tax system, explicitly reduce tax policy gap and stimulate economic growth. During 1990's a country experienced economic reforms in trade liberalisation embraced fiscal reforms on tax revenue with objectives of raising tax revenue, increase equity on the tax system, reduce the tax burden, introduce incentives to producers and investors, widening the tax base and simplifying tax structure and administration. Osoro [13], Fjeldstad [16]. Nevertheless, a country experiences several fiscal reforms but still offsetting budget gap depend on foreign and internal debts.

Many countries include Tanzania faces challenges in archiving tax frontier due to endogenous and exogenous factors, government or industry can control endogenous factors such as technical efficiency, economic factors and institutions that determine the ability of the government to collect tax revenue. However, there are exogenous variables, which cause inefficient in tax collection, but they can not influence them. There are several studies conducted to find out whether a country has collected enough tax revenues to finance its budget by using different methodologies; tax potential, tax ratio and tax efforts. Generally, tax revenue is the primary source of government revenue in which failure to collect enough tax revenue will lead to government spending shock and increase the cost to the government through new borrowings to offset the budget deficit gap.

The first objective of this paper is to assess whether potential tax determinants can influence tax revenue performance; the second objective provides an opportunity to understand the extent of variables effects regarding tax revenue and finally, findings contribute to the literature review.

This paper arranged into eight sections; the introduction in section one, section two is a literature review, then followed by a statement of the problem in section three, research question in section four. Research methodology in section five, data and empirical results in section six, discussion regarding the results in section seven and lastly conclusion in section eight.

\section{Literature Review}

Researches which intended to find out the causes of low tax capacity in developing countries reflected on earlier studies, Lotz and Morris [9] conducted a study on tax efforts in developing countries using tax ratio based on tax 
revenue per GDP and ranked 72 countries; results indicated that the higher the tax effort ranking, the closer the country's tax capacity. When analysing economic sector with tax ratio, mining and non-mineral export found positively affect tax ratio, and comparison between countries vary due to the specific country differences.

Countries include Sub Saharan Africa are struggling to raise tax revenue to finance various public expenditure, but due to high dependence on agriculture, poor structure of tax revenue, weak tax administration, and low per capita income, and as a result, it is challenging for them to raise required tax revenue and meet development goals. The Analysis which examine tax efforts in Sub Saharan Africa using panel data from 43 countries, results suggest to use potential tax base to raise tax revenues as well as providing a guideline on fiscal policy mix during budget imbalance. Furthermore, agriculture and mining share revealed negatively and significantly; export shares revealed positively and significantly; per capita income found not significantly, and tax share on average revealed no any link with funds programs. Stotsky and WoldeMariam [18]

Various countries emphasise on improving resource mobilisation and reduce debt dependency through improving significant economic and institutional factors, but trend indicates other countries manage to improve tax revenue collection, while several developing countries lag behind with low tax ratio. Gupta [6] conducted a study on determinant factors of tax revenue in developing countries; results indicated that structural factors GDP per capital, agriculture share, trade openness, foreign aid and corruptions are significant and strongly essential determinants of tax revenues. Suggest for developing countries to focus on imposing a tax on income, profit and capital gain to improve tax revenue performance.

Budget deficit caused by expansion of government spending while tax collection remain low, Karagöz [7] examine tax determinants that affect tax performance in Turkey; results indicated that agriculture and industrial share, external debt stock, monetisation rate of economy and urbanisation rate affect tax revenue significantly while the openness to foreign trade does not affect tax revenue performance.

In searching factors which help developing countries to increase tax revenue performance, Bird [2] suggest to improve the effectiveness of social institutions such as the rule of law and fighting corruption may no longer necessary instead advocate on restructuring opportunities for tax handles and economic reform and focusing on improving non-agriculture sector and promote imports and export. Insist not only supplying factor but also social institutions significantly determine tax efforts.

Many countries undergo trade liberation to boost economic activities with the assumption that, trade openness could increase economic growth as well as tax revenue. Nezhad et al. [11], examine whether trade liberalisation tends to increase tax revenue performance of 83 countries from 1990 to 2012 using generalised method of moment regression, results indicated that GDP growth, agriculture share, exchange rate, urbanisation and democracy are potential determinants of tax revenue. In increasing tax revenues, government shall determine an appropriate macroeconomic policy to enhance trade liberation.
Despite, several countries attempted to reform their economic structure, but the tax revenue remained low, and part of the government budget continue to be financed by public debts. Chaudhry and Munir [4] analyzed the determinant of low tax revenue in Pakistan and found openness, broad-money, external debt, foreign aid, and political stability were statistical significant, additional results revealed performance of low tax revenue caused by narrow tax base, high dependence on agriculture sector, foreign aid and low level of literacy rates. Propose improving trade openness, literacy level, stability on political, extend tax base and control significant factors can increase performance on the tax to GDP ratio.

Implementation of tax policy that intended to improve the performance of tax revenue requires special attention and close monitoring of its enactment throughout the fiscal year, the poor performance of tax revenue caused by several factors. Ngotho and Kerongo [15] examine the determinant of revenue collection in Kenya in administrative perspectives. Results indicated the level of compliance and tax rates affected revenue collection. However, the FDI and Inflation influence revenue performance to the certain extent and suggest sensitisation on the importance of tax to improve tax compliance.

Tax efforts used to measure country's ability to collect tax revenue, the analysis of tax efforts, which involved many countries need a careful interpretation of results because countries vary numerous specific features, which influences tax performance. Eltony [10] investigate 16 Arab countries regarding difficulties in raising sufficient tax revenue using pooled time series and cross-sectional data from 1994 to 2000. Results suggest that per capita income, agriculture share, and mining share are primary determinants of tax revenue to GDP ratio. Other factors influence tax ratio includes exports share, imports share and external debts, however, the non-oil Arab countries found external debt statistically significant and positively associated with tax ratio. Emphasised on Arab countries to increasing tax revenue instead of rationing expenditure while Tunisia, Algeria, Morocco and Sudan suggested reforming the tax system.

Gobachew et al. [14] investigated the determinants of tax revenue in Ethiopia and results revealed agriculture share and inflation are statistically significant and negatively affect tax revenue, the industry share and trade openness revealed significant and positive affects tax performance, foreign direct investment found insignificantly and negatively affect tax revenue. However, Ethiopian's tax performance indicate promising, but the GDP ratio remained low which attract enhancement of tax revenue performance.

Castro and Camarillo [1]. Analyse the determinants of tax revenue in OECD countries using static and dynamic panel data techniques over the period 2001-2011. Factor determinant, which influences tax revenue, varies across OECD Countries, however, per capita, trade volume; foreign direct investment, civil liberties, political rights and life expectancy have similar results across the countries. Additional results, which varies between middle income and high income include agriculture share; infant mortality rate has positive coefficient while industries and proxy of education indicated negative coefficient in middle-income countries. 
These empirical studies provide evidence that each country needs to be examined separately regarding tax determinant factors that influence tax revenue performance in the country.

\section{Statement of the Problem}

Financing recurrent expenditure and development projects need a country to have sustainable tax performance with high tax capacity that aligned with the expansion of government spending. Tanzania experienced numerals of fiscal reforms, which intend to improve tax revenue performance and avoid significant budget imbalances that can lead to high fiscal debt dependence. With historical fiscal reforms, a country's tax capacity still needs improvement. Understanding key determinant factors and the extent of effects are prerequisites for policymakers because it provides an opportunity to recognise the critical tax determinants.

\section{Research Question}

Developed a research question of how to increase public revenue to enhance the ability of the government to finance its budget using an internal source of fund, Research question intends to find out whether tax determinant can improve tax performance. Generally, a country receives public revenue from various sources such as taxes, fees and charges, penalty, and royalty, but tax is the main source of income.

\subsection{The Research Hypothesis}

The following hypothesis was developed to respond to the research question:-

$H_{0}$ Potential tax determinants affect tax performance

$\mathrm{H}_{1}$ Potential tax determinants does not affect tax performance.

\section{The Methodology of the Study}

This study initially uses the first equation of tax function following Gaalya [5], the tax function comprises tax revenue to GDP ratio as a dependent variable and function as a vector of independent tax bundles which referred as potential tax determinants. The tax function is given as follows:-

$$
\frac{T_{t}}{Y_{t}}=f\left(T X_{t}\right)
$$

Whereby:-

$T_{t}=$ Tax revenue (Perfomance of tax)

$Y_{t}=G D P$ of the country

$\frac{T_{t}}{Y_{t}}=$ Tax ratio to GDP

$T X_{t}=$ Vector of tax bundles

$t=$ as a subscript equal to time.

We transform equation [1] into econometric form and incorporate all tax component variables; economic variables, structural variables, institutional variables, and financing variables. The econometric model is equal to:-

$$
\frac{T_{t}}{Y_{t}}=\alpha_{0}+\beta_{1} \theta_{1}+\beta_{2} \omega_{1}+\beta_{3} \delta_{1}+\beta_{4} \pi_{1}+\mu
$$

Whereby:-

$$
\begin{aligned}
& \frac{T_{t}}{Y_{t}}=\text { total tax revenue per GDP ratio (tax ratio) } \\
& \theta_{1}=\text { Economic variables } \\
& \omega_{1}=\text { Structural variables } \\
& \delta_{1}=\text { Institutional variables } \\
& \pi_{1}=\text { Financing variables } \\
& \beta_{1} \text { to } \beta_{4}=\text { coefficient to be estimanted } \\
& \alpha_{0}=\text { constant term and } \mu \text { is the error term. }
\end{aligned}
$$

In estimating time series data, the estimation equation incorporate tax components as follows:-

$$
\begin{aligned}
\frac{T_{t}}{Y_{t}}= & \alpha_{0}+\beta_{1} M N_{i t}+\beta_{2} M G_{i t}+\beta_{3} C S_{i t}+\beta_{4} T R_{i t} \\
& +\beta_{5} S R_{i t}+\beta_{6} T D_{i t}+\beta_{7} F D_{i t}+\beta_{8} G E_{i t} \\
& +\beta_{9} R Q_{i t}+\beta_{10} R L_{i t}+\beta_{11} C R_{i t} \\
& +\beta_{12} \log L N_{i t}+\beta_{13} L_{o g} G R_{i t}+\mu .
\end{aligned}
$$

The descriptive of the variables used in equation [3] provided in Table 1.

Table 1. Descriptive statistics

\begin{tabular}{|l|l|l|l|}
\hline Variables & Tax determinant variables & Abr. & Particulars \\
\hline Dependent Variable & Tax Revenue per GDP & T/Y & Total tax revenue /Gross Domestic Product \\
\hline \multirow{4}{*}{ Economic Variables $\left(\theta_{1}\right)$} & Mining share & MN & Mining and Quarrying/ Gross Domestic Product \\
\cline { 2 - 4 } & Manufacturing Share & MG & Manufacturing/ Gross Domestic Product \\
\cline { 2 - 4 } & Construction & CS & Construction/ Gross Domestic Product \\
\cline { 2 - 4 } & Transport share & TR & Transport and storage per GDP \\
\cline { 2 - 4 } Structural Variable $\left(\omega_{1}\right)$ & Services & SR & Services/ Gross Domestic Product \\
\hline \multirow{4}{*}{ Institutional Variables $\left(\delta_{1}\right)$} & International Trade openness & TD & (Import Tax+ Export Tax)/Gross Domestic Product \\
\cline { 2 - 4 } & FDI & FD & Foreign Direct Investment per GDP \\
\hline \multirow{3}{*}{ Financing Variables $\left(\pi_{1}\right)$} & Government Effectiveness & GE & Government Effective \\
\cline { 2 - 4 } & Regulatory Quality & RQ & Regulatory Quality \\
\cline { 2 - 4 } & Rule of Law & RL & Law of order \\
\cline { 2 - 3 } & Corruption & CR & Control of Corruption \\
\cline { 2 - 3 } & Loan Share & LN & logarithm of Loan \\
\cline { 2 - 3 } & Grant Share & GR & logarithm of Grant \\
\hline
\end{tabular}




\section{Data and Empirical Results}

Annual data covering a period from 1999 to 2015 used during the analysis, tax revenue data obtained from Tanzania Revenue Authority (TRA), country GDP data obtained from Tanzania Bureau of Statistics (NBS). Data for economic variables and financing variables obtained from annual reports published by Bank of Tanzania (BOT), and institutional variables obtained from World Development Indicator. All these data and reports are freely available online.

The analysis at first, find the relationship between variables using coefficient correlation, the results indicate that the mining and quarrying share, trade openness, foreign direct investment share, corruption level, loan, and grants ware highly and positively correlated with tax ratio. The manufacturing, transportation, agriculture, government effectiveness and the rule of law negatively correlated with the tax ratio. The corrections between tax performance and other variables shown in Table 2 .

Tolerance coefficient and variable inflation factor used to measure and ensure no multicollinear persist in the variables, regression analysis assess if potential tax determinants influence the tax performance in Tanzania. The results indicate $\mathrm{R}$ 0.995, Durbin-Watson 2.446, adjusted $\mathrm{R}$ square $0.977, \mathrm{~F}$ value 56.807 and $\mathrm{P}$ value equal to 0.01 , which is less than 0.05 . In respect to these results, we fail to reject the null hypothesis that potential tax determinants significantly influence tax performance in Tanzania. The regression analysis results provided in Table 3.

Table 2. Coefficient Correlation

\begin{tabular}{|c|c|c|c|c|c|c|c|c|c|c|c|c|c|c|}
\hline$A B R$ & $T / Y$ & $M N$ & $M G$ & $C S$ & $T R$ & $S R$ & $T D$ & $F D$ & $G E$ & $R Q$ & $R L$ & $C R$ & $L N$ & $G R$ \\
\hline$T / Y$ & 1 & & & & & & & & & & & & & \\
\hline$M N$ & $.721^{* *}$ & 1 & & & & & & & & & & & & \\
\hline$M G$ & -.123 & $-.742^{* *}$ & 1 & & & & & & & & & & & \\
\hline$C S$ & .263 & $.811^{* *}$ & $-.960^{* *}$ & 1 & & & & & & & & & & \\
\hline$T R$ & -.053 & $-.570^{*}$ & $.663^{* *}$ & $-.558^{*}$ & 1 & & & & & & & & & \\
\hline$S R$ & -.015 & $-.625^{* *}$ & $.964^{* *}$ & $-.951^{* *}$ & $.521^{*}$ & 1 & & & & & & & & \\
\hline$T D$ & $.911^{* *}$ & $.563^{*}$ & .019 & .120 & -.018 & .100 & 1 & & & & & & & \\
\hline$F D$ & .436 & .022 & .377 & -.294 & .330 & .407 & $.573^{*}$ & 1 & & & & & & \\
\hline$G E$ & $-.700^{* *}$ & $-.572^{*}$ & .298 & $-.469^{*}$ & -.191 & .349 & $-.689^{* *}$ & -.342 & 1 & & & & & \\
\hline$R Q$ & -.027 & -.165 & .005 & -.001 & .440 & -.132 & -.061 & -.167 & -.265 & 1 & & & & \\
\hline$C R$ & .414 & $.490^{*}$ & -.170 & .120 & $-.673^{* *}$ & .036 & .350 & -.058 & .183 & -.336 & -.208 & 1 & & \\
\hline$L N$ & $.751^{* *}$ & $.911^{* *}$ & $-.644^{* *}$ & $.785^{* *}$ & -.273 & $-.611^{* *}$ & $.644^{* *}$ & .119 & $-.841^{* *}$ & .032 & $-.633^{* *}$ & .203 & 1 & \\
\hline$G R$ & $.872^{* *}$ & $.691^{* *}$ & -.096 & .215 & -.242 & .026 & $.817^{* *}$ & .402 & $-.537^{*}$ & -.291 & $-.661^{* *}$ & $.538^{*}$ & $.668^{* *}$ & 1 \\
\hline
\end{tabular}

Source: Authors computation.

Table 3. Regression Results of Potential Tax Determinant

\begin{tabular}{|c|c|c|c|c|c|}
\hline Model Variables & Abbreviation & Coefficients & Std. Error & t stat & Sig. \\
\hline (Constant) & & .092 & .111 & .826 & .455 \\
\hline Mining and Quarrying & $\mathrm{MN}$ & 5.406 & 1.332 & 4.057 & .015 \\
\hline Manufacturing & MG & .481 & 1.180 & .407 & .705 \\
\hline Construction & CS & .643 & .592 & 1.086 & .339 \\
\hline Transport & TR & 2.080 & .931 & 2.233 & .089 \\
\hline Services & SR & .198 & .198 & .999 & .374 \\
\hline Trade openness & $\mathrm{TD}$ & .864 & .341 & 2.532 & .065 \\
\hline FDI & FD & -.226 & .132 & -1.717 & .161 \\
\hline Government Effectiveness & GE & -.239 & .074 & -3.247 & .031 \\
\hline Regulatory Quality & RQ & .036 & .032 & 1.115 & .327 \\
\hline Rule of Law & $\mathrm{RL}$ & .062 & .045 & 1.363 & .244 \\
\hline Control of Corruption & $\mathrm{CR}$ & .029 & .023 & 1.276 & .271 \\
\hline Loan & LN & -.098 & .031 & -3.170 & .034 \\
\hline Grant & GR & .019 & .017 & 1.141 & .317 \\
\hline $\mathrm{T} / \mathrm{Y}=$ Dependent Variable & & & & & \\
\hline
\end{tabular}

Source: Authors computation. 
The regression results indicated that mining and quarrying, trade openness and loan are statistically significant and positively affect tax performance while the government effectiveness revealed negative coefficient but significantly. Manufacturing share, construction share, transport share, services share, regulatory quality, the the rule of law and corruption positively affect tax ratio insignificantly while loan and foreign direct investment are negatively affected tax revenue performance but insignificantly.

\section{Discussion of Tax Performance}

The empirical results regarding tax revenue determinant vary across the countries however there are some variables revealed same results with Tanzania. Discussion regarding tax revenue determinants focused on output results and linked with the enactment of some policy with the intention of raising public revenue.

Mining share revealed highest positive coefficient and significantly affect the performance of tax revenue. This result also aligned with Eltony, [10] in non-Arab oil countries, Improving policy that attracts new investment in mining extraction is not currently advisable in Tanzania because Simbachawene and $\mathrm{Li}$ [12] argued extraction of minerals does not benefit a country in term of tax and royalty. Minerals are nonrenewable resources; henceforth mining policy shall consider efficiency rate of mineral extraction and reserve amount of deposit for future generation. For the time being, emphasis shall focus on improving economic rent in existing mining companies through improving the effectiveness of mining laws and immunise tax structure to ensure it can resist complications arises in the mining sector. Additionally, emphasis shall consider establishing a mechanism that will control and limit some of the mining production cost as well as reduce excessive tax relief. In Tanzania mining sector dominated by sizeable Multinational Corporation, which claimed to cause inefficient of tax performance through reporting under-profit, developing complex structure, exploiting ambiguities in tax laws and repatriate taxable income from developing countries in collaboration with local staff. Otusanya [17]. To avoid such practice; a country shall increase the effectiveness of the existing mineral laws, strengthen respective institutions and introduce appropriate control mechanism to ensure no tax evasion or avoidance.

Results in manufacturing share were expected and aligned with previous studies, Chaudhry and Munir [4], Castro and Camarillo (2014) [1], Gobachev et al. [14] who found manufacturing share has a positive effect with tax performance. The manufacturing sector is among the essential sectors in boosting economic growth that claimed to associate with an increase in tax revenue performance. The manufacturing sector in developing countries lag behind, and discussion on how to improve manufacturing sector in Tanzania is a lengthy discussion. As per economic development theories, Lewis [19] a country shall continue emphases on the transformation of the traditional economy (agriculture) to industrial through structural transformation of industrialisation, informal sector, urbanisation that will help bring more taxpayers into the tax net. Tanzania can learn more from successfully country like China, which has effectively and successfully implemented economic transformation change.

Construction share, transport share and service share both have a positive effect on tax performance; hence, the government shall continue improving and unlocking any investment constraints in these economic sectors.

Openness to international trade affects tax performance with the coefficient value of 0.588 , and insignificantly, it aligned with several previous researchers who support capacity of tax collection is associated with trade openness due to access of imposing a tax on import or export of any product easily. Chaudhry and Munir [4], Gorbachev et al. [14]. Policymakers shall continue to create a conducive environment and focus on modern technique on promoting export trade especially with those countries whose consumption products are available in Tanzanian.

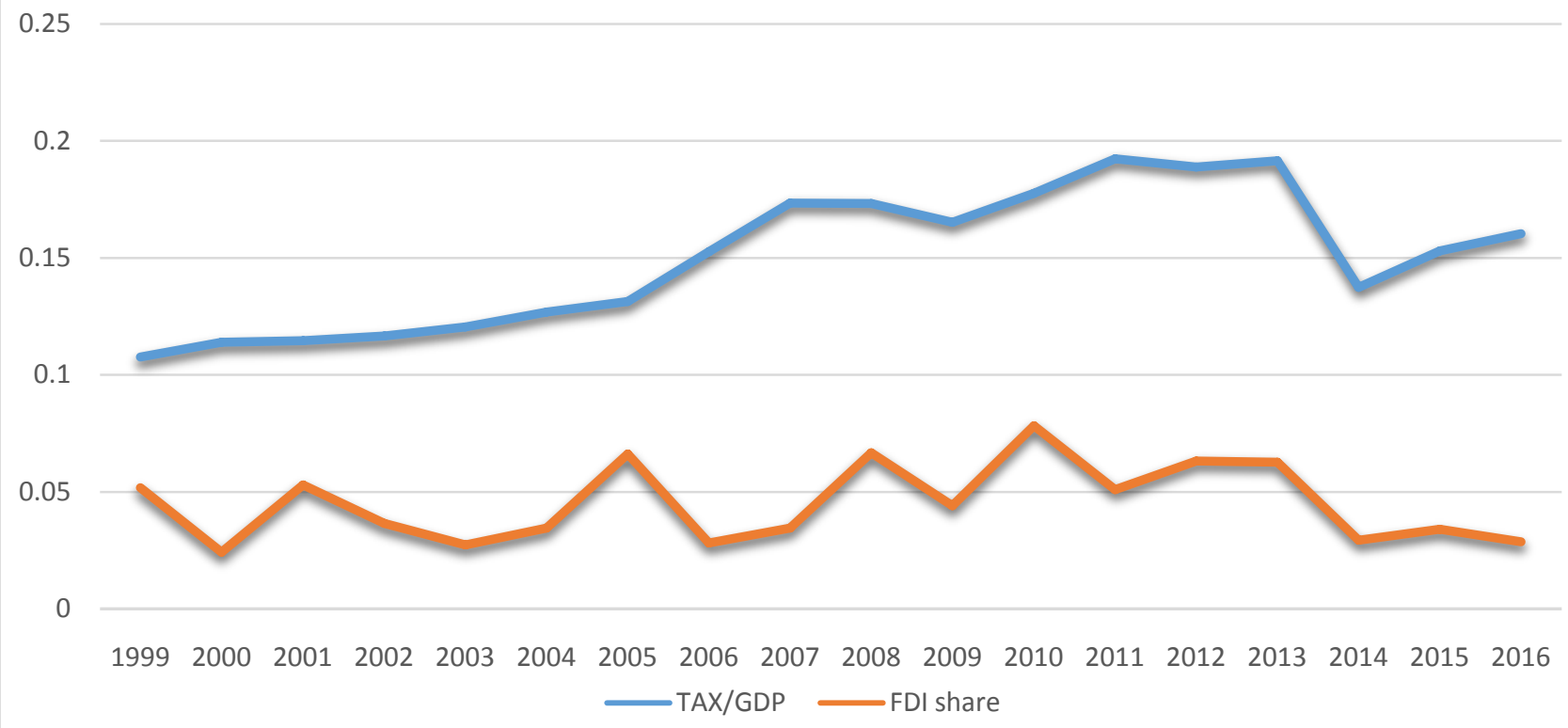

Figure 1. The Trend of Tax Ratio VS FDI Share 


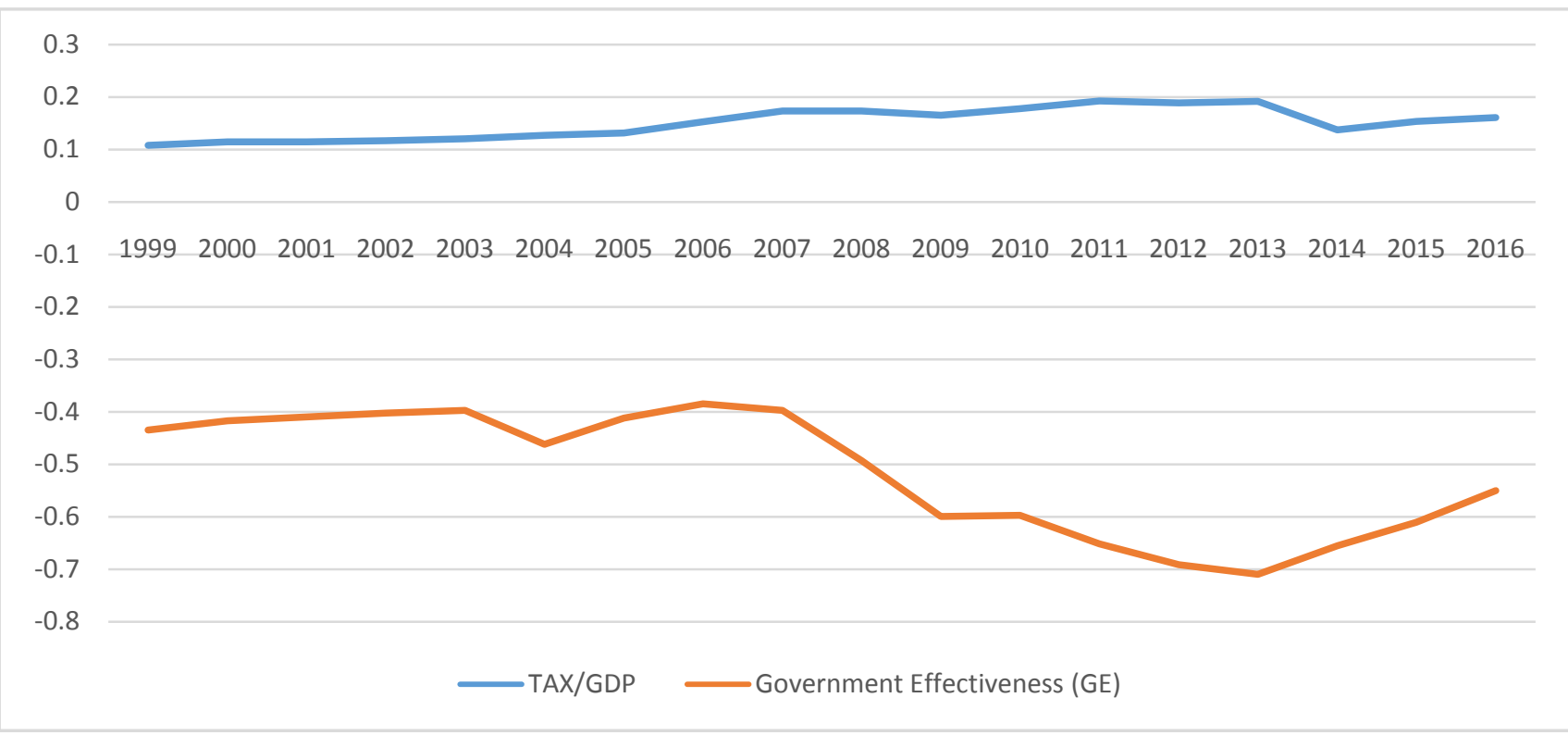

Figure 2. The Tax Ratio VS Government Effectiveness

The variables FDI share revealed negative coefficient of nearly of $0.23 \%$ and significantly; this is an unexpected result for developing country like Tanzania. However, these findings also aligned with previous studies Castro and Camarillo [1], Gorbachev et al. [14]. During economic reform and trade liberalisation in 1990's, foreign direct investment policy structured with an excessive tax exemption for short and long-term which benefit foreign investors greatly for paying little or no tax. Highly dependence on foreign direct investment is not a good option for increasing tax revenue because countries tend to set lower tax or tax exemption due to the competition of attracting FDI. A country can promote local industries through, encourage companies to increase investment base on scientific research, adherence to independent innovation, guide the industry cluster development, broaden financing and continue to encourage private capital participation. $\mathrm{Li}$ and Wei [8] The emphasis should focus on prioritising and establish an appropriate mechanism for promoting local technology and investment to reduce foreign investment dependence. Suggest reviewing FDI policy and asses whether it achieve policy objectives or country benefit from another significant economic advantage. Otherwise, the existing foreign direct investment policy shall redefine policy objectives and incorporate all tax matters. The trend between FDI share and Tax ratio in Figure 1, shows FDI share has been fluctuating since 1999 to date, and in the year 2000, 2003, 2006 and 2014 has the lowest value while the tax revenue performance is increasing since 1999. In the year 2014 to 2016, FDI share indicates a slight decline, while the tax revenue performance increased sharply.

Furthermore, the fluctuation of tax revenue to GDP ratio has increased with an average of $41 \%$ while the fluctuation of FDI has an average of negative of 13\%, Base on this trend analysis, it clearly implies that FDI share in Tanzania does not affect tax revenue performance rather increase in tax revenue was contributed by other factors.

The country's Institutional capacity expected to contribute significantly to the tax performance but government effectiveness revealed negative coefficient. It means during a period under review; government effectiveness did not influence the performance of tax revenue in Tanzania, hence if the theory hold as seen from 2014 to 2016; it means Tanzania wasted tax revenues from 2007 to 2014 due to the failure of strengthening the effectiveness of government. Additional trend analysis between government effectiveness and tax revenue performance indicated in Figure 2, shows that a score of government effectiveness tend to fluctuate with the weakest level in 2003 and keep declining from 2007 to 2014 while the tax performance improves throughout the years. Since 2014 to 2016, the trend of both government effectiveness and tax performance improved which aligned with the theory.

Results for regulatory quality, the rule of law and control of corruption both influence tax performance; government shall continue emphasising the effectiveness and prioritise the national interest. Several studies support the Institutional variables associated with tax collection capacity, the weak the institutional the less the tax capacity, such as the law of order, which used to determine the ability of the government to capture and enforce tax policy. Castaneda and Pardinas [3]

Financing variable reveals expected results for a loan; it implies that reducing the amount of new loan by one unit will tend to increase the tax revenue performance by 0.098, grant results reveal positively affect tax revenue performance although it is insignificant. Emphasize should focus on mobilising more source to increase public revenue and reduce the debt level.

\section{Conclusion}

Conclude that variables included in the model have significantly influenced the performance of tax revenue, suggest government shall continue improving tax policy, strengthen institutions and maintain existing financing structure, which correlates with tax performance and aligned with economic theories. Continuously assessment of economic sector performance and its effectiveness regarding tax policy and immediately solve any identified tax policy gap to avoid adverse effects in economic performance. 
Mining and quarrying sector, emphasised on the effectiveness of tax laws on the existing mining investment, control utilisation of new mineral resources sites for the future generation, reviewing investment policy objectives and attract renegotiation of FDI agreement that contributes to non-tax payment. Learn and apply best practice on economic transformation-change from agricultural dependence to industrialisation, which claimed to associate with higher tax capacity. Stimulating economic growth and mobilise more resources to improve tax revenue such as introducing new market-based approach and reducing regulatory control approach.

\section{References}

[1] Ángeles Castro, G., and Ramírez Camarillo, D.B. (2014). Determinants of tax revenue in OECD countries over the period 2001-2011. Contaduría Y Administración, 59(3).

[2] Bird, Richard M Jorge Martinez-Vazquez., Benno Torgler (2014), Societal Institutions and Tax Effort in Developing Countries, Annals of Economics and Finance, 15(1).

[3] Castaneda, Luis and Pardinas, Juan, (2012), Sub-National Revenue Mobilization in Mexico. IDB Working Paper No. IDB-WP-354.

[4] Chaudhry, I. S., and Munir, F. (2010). Determinants of Low Tax Revenue in Pakistan. Pakistan Journal of Social Sciences (PJSS), 30(2).

[5] Gaalya, M.S., Edward, B. and Eria, H. (2017) Trade Openness and Tax Revenue Performance in East African Countries. Modern Economy, 8.

[6] Gupta, S. A. (2007). Determinants of Tax Revenue Efforts in Developing Countries. International Monetary Fund (IMF) Working Paper 07/184
[7] Karagöz, K. (2013). Determinants of Tax Revenue: Does Sectorial Composition Matter? Journal of Finance, Accounting and Management, 4(2).

[8] Li Xiangju and Du Wei (2015) Policy Research to promote the development of emerging industries for local government-A case of Shaanxi aerospace industry. (9).

[9] Lotz, J.R. and E.R. Morss. (1967). Measuring Tax Effort in Developing Countries. International Monetary Fund Staff Papers, 14(3).

[10] M. Nagy Eltony, (2002). Measuring Tax Effort in Arab Countries, Economic Research Forum Working Papers Series, WP No. 0229.

[11] Mansour Zarra Nezhad, M. S. A. and M. M. (2016). Determinants of Tax Revenue: Does Liberalization Boost or Decline It? Journal of Economic Cooperation and Development, 37 (2).

[12] Method Simbachawene and Xiangju Li, (2018), Does Ridge Coefficient Deliver Alpha? The Analysis of Mineral Resource Tax Performance in Tanzania, American Journal of Economics 2018, Vol.8 No. 2.

[13] Nehemiah E Osoro, (1995) Tax Reforms in Tanzania: motivations, directions and implications, AERC Research Paper 38.

[14] Neway Gobachew, Kenenisa Lemie Debela and Woldemicael Shibiru, (2018). Determinants of Tax Revenue in Ethiopia. Economics. Vol. 6, No. 1.

[15] Ngotho, J., \& Kerongo, F. (2014). Determinants of Revenue Collection in Developing Countries: Kenya's Tax Collection Perspective. Journal of Management and Business Administration, 1(1).

[16] Odd-Helge Fjeldstad, (1995) Taxation and tax reforms in Tanzania: a survey, Chr Michelsen Institute CMI working paper 1995: 4.

[17] Olatunde Julius Otusanya, (2011), The role of Multinational companies in tax evasion and tax avoidance: The case of Nigeria, Critical Perspectives on Accounting 22 (2011).

[18] Stotsky, J. G., \& WoldeMariam, A. (1997), Tax Effort in SubSaharan Africa. Retrieved from http://papers.ssrn.com/abstract=882633.

[19] W. Arthur Lewis, (1955), Theory of Economic Growth London: George Allen \& Unwin. 